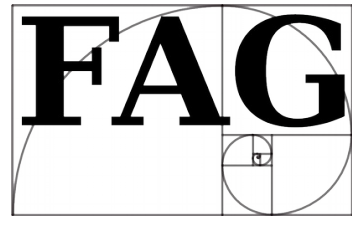

Filozoficzne Aspekty Genezy — 2015, t. 12

Philosophical Aspects of Origin

s. $147-166$

http://www.nauka-a-religia.uz.zgora.pl/images/FAG/2015.t.12/art.09.pdf

Alfred Russel Wallace

\title{
O prawie, które kierowało pojawianiem się nowych gatunków *
}

\footnotetext{
*Alfred Russel Wallace, „On the Law Which Has Regulated the Introduction of New Species", The Annals and Magazine of Natural History, Including Zoology, Botany, and Geology 1855, vol. XVI (Second Series), s. 184-196. Z języka angielskiego przełożył Grzegorz MaLEC.

(Przyp. tłum.) Alfred Russel Wallace (1823-1913) był brytyjskim przyrodnikiem, podróżnikiem i kolekcjonerem okazów przyrodniczych. Wallace jest znany głównie z tego, że niezależnie od Darwina sformułował teorię ewolucji drogą doboru naturalnego. Ewolucjonistyczne poglądy Wallace'a i Darwina zostały przedstawione w roku 1858 na spotkaniu Towarzystwa Linneuszowego - tekst Wallace'a został przetłumaczony przez Kazimierza Szarskiego i opublikowany w setną rocznicę ukazania się O powstawaniu gatunków (por. Alfred Russel WALLACE, „O dążności odmian do nieograniczonego odbiegania od typu pierwotnego", w: Kazimierz Petrusewicz (red.), Teoria ewolucji w wypisach: Lamarck - Wallace — Darwin, Wiedza Powszechna, Warszawa 1959, s. 81-91). Najpełniejsze studium poglądu o transmutacji gatunków zostało wyrażone przez Wallace'a po śmierci Darwina w obszernej książce Darwinism (por. Alfred Russel WALLACE, Darwinism; an Exposition of the Theory of Natural Selection, with Some of Its Applications, Macmillan and Co., London - New York 1889). Fragmenty tej książki zostały przełożone na język polski przez znanego popularyzatora nauki, geologa i ewolucjonistę Marcina Ryszkiewicza (por. Marcin Ryszkiewicz, Alfred Russel Wallace. W cieniu Darwina, Wydawnictwa Uniwersytetu Warszawskiego, Warszawa 2008).

W 1854 roku Wallace z uwagą przeczytał artykuł Edwarda Forbesa, który twierdził, że na podstawie posiadanych danych paleontologicznych można wywnioskować, iż życie na Ziemi pojawiało się zgodnie $\mathrm{z}$ boskim zamysłem. Forbes postulował dualistyczną periodyzację geologiczną, która była zgodna z jego teorią biegunowości. Uczony utrzymywał, że proces stwarzania organizmów żywych odbywał się we wczesnym Paleozoiku i późnym Neozoiku. Wallace na podstawie podobnych obserwacji doszedł do diametralnie różnych wniosków i odrzucił pogląd Forbesa o nadnaturalistycznym pochodzeniu organizmów żywych. Przyrodnik pod wpływem poglądów Charlesa Lyella był przekonany, że nieustające i stopniowe oddziaływanie procesów geologicznych wywołuje ciagłe przeobrażenia skorupy Ziemi. Zmiana poszczególnych środowisk wywierała presję na organizmy żywe, których budowa fizyczna, odpowiednio przystosowując się do nowych warunków, musiała ulegać ciągłym zmianom. Wallace nie znał wówczas mechanizmu zmienności (doboru naturalnego), ale twierdził, że zapis geologiczny, wbrew temu, co pisał Forbes, nie dostarcza świadectw na rzecz nadnaturalistycznego pochodzenia gatunków, ale łączy wszystkie gatunki naturalnymi łańcuchami pokrewieństwa, co można przedstawić jako drzewo życia.
} 
Każdy przyrodnik, który interesował się zagadnieniem rozmieszczenia geograficznego zwierząt i roślin, zapewne zastanawiał się nad pewnymi osobliwymi faktami występującymi w przyrodzie. Wiele z nich znacząco odbiega od tego, czego można by oczekiwać, i dotychczas uważane były za wysoce interesujące, ale zupełnie niewythumaczalne. Żadne wyjaśnienia stosowane od czasów Linneusza * nie są uważane współcześnie za w pełni zadowalające — żadne nie było w stanie wyjaśnić tego, co wiedziano ówcześnie, jak również faktów, które dane nam było poznać obecnie. Badania geologiczne, które w ostatnich latach rzuciły dużo światła na zagadnienie rozmieszczenia geograficznego organizmów, wykazały, że obecny stan geologiczny Ziemi i organizmów ją zamieszkujących to zaledwie ostatni etap długiej i nieprzerwanej serii zachodzących zmian. Dlatego też próby wyjaśnienia oraz opisu ich bieżącego stanu bez żadnego odniesienia do zmian, które zaszły w przeszłości (jak to zazwyczaj czyniono), muszą prowadzić do bardzo wątpliwych i błędnych wniosków.

Oto krótki zestaw faktów dowiedzionych przez geologię:

- Podczas pewnego ogromnego, ale nieznanego okresu geologicznego ** powierzchnia Ziemi przechodziła stopniowe zmiany. Ląd obniżał się poniżej poziomu oceanu, a z niego wyłaniały się nowe lądy, łańcuchy górskie ulegały wypiętrzeniu, wyspy przeradzały się w kontynenty, a kontynenty zatapiały się aż do postaci wysp. Zmiany te nie zaszły tylko raz, lecz setki, a być może nawet tysiące razy.

— Wszystkie te procesy odbywały się mniej lub bardziej płynnie, ale z różnym natężeniem. W tym czasie życie organiczne na Ziemi przechodziło od-

\footnotetext{
* (Przyp. tłum.) Karol Linneusz (1707-1778), szwedzki przyrodnik i wieloletni profesor na Uniwersytecie w Uppsali. Linneusz był twórcą binominalnego nazewnictwa taksonomicznego i autorem obszernego dzieła Systema naturae, w którym opisał wszystkie ówczesne znane gatunki zwierząt i roślin. Jego nazwisko powszechnie łączy się z poglądem o niezmienności gatunków, ale Linneusz pod koniec życia stwierdził, że nie gatunki, ale rodzaje są niezmienne.

** (Przyp. thum.) W połowie dziewiętnastego wieku większość przyrodników akceptowała pogląd Johna Phillipsa, że w historii Ziemi można wyróżnić trzy główne ery: Paleozoik, Mezozoik i Kenozoik (ery te dzieliły się na okresy, a okresy na epoki). Reprezentowały one istnienie różnych grup organizmów (u Phillipsa głównie bezkręgowców), zatem kryterium podziału stratygraficznego było występowanie skamieniałości w poszczególnych warstwach skalnych (por. David N. Reznick, The Origin Then and Now: An Interpretive Guide to the Origin of Species, Princeton University Press, Princeton 2010, s. 269).
} 
powiednie modyfikacje w zależności od zmian środowiskowych. Choć modyfikacje te miały charakter stopniowy, to ich efekty były całkowite - po pewnym czasie żaden gatunek nie zachował się w swojej uprzedniej formie. Wydaje się, że całkowite przeobrażenie form życia miało miejsce wielokrotnie.

— Zmiany w przyrodzie ożywionej na przestrzeni wszystkich epok geologicznych zachodziły stopniowo. Pierwsze pojawienie się współczesnych zwierząt może w wielu przypadkach zostać prześledzone. Liczba jednych gatunków sukcesywnie wzrastała w młodszych formacjach geologicznych, podczas gdy inne organizmy stopniowo wymierały i wygasały. Obecny stan świata organicznego jest w konsekwencji wyraźnym skutkiem naturalnego procesu stopniowego wymierania i pojawiania się gatunków * wywodzących się z tych, które istniały w poprzednich okresach geologicznych. Możemy zatem bezpiecznie wyciągnąć wniosek o podobnej stopniowalności i naturalnym następstwie w każdej epoce geologicznej.

Traktując powyższe jako uzasadnione stwierdzenia będące rezultatem dociekań geologicznych, widzimy, że współczesne rozmieszczenie geograficzne życia na Ziemi musi być wynikiem wszystkich wcześniejszych zmian, zarówno zmian powierzchni Ziemi, jak i jej mieszkańców. Bez wątpienia działało wiele przyczyn, które na zawsze pozostaną dla nas tajemnicą, dlatego możemy oczekiwać, że dokonamy wielu odkryć niezwykle trudnych do wyjaśnienia. Wszelkie próby wyjaśnień muszą uwzględniać wpływ zmian geologicznych, które $\mathrm{z}$ dużym prawdopodobieństwem mogły mieć miejsce, aczkolwiek nie posiadamy bezpośrednich świadectw ich poszczególnego oddziaływania.

*(Przyp. thum.) Wallace użył w tym miejscu wyrażenia „creation of species”. Przyrodnik używał terminu „stworzenie” w takim samym znaczeniu jak Darwin — pojawienie się gatunków na mocy nieznanego procesu przyrodniczego (por. Peter RaBY, Alfred Russel Wallace: A Life, Princeton University Press, Princeton 2001, s. 103). John van Wyhe, badacz historii ewolucjonizmu, w obszernej monografii poświęconej Wallace'owi cytował przewodniczącego Towarzystwa Geologicznego, który jeszcze przed publikacją $\mathbf{O}$ powstawaniu gatunków oznajmił, że termin „stworzenie” oznacza stwierdzenie pojawienia się danego organizmu bez określenia charakteru tego procesu (por. John van WyHE, Dispelling the Darkness: Voyage in the Malay Archipelago and the Discovery of Evolution by Wallace and Darwin, World Scientific Publishing, Singapore 2013, s. 110). 
Wielki rozwój wiedzy na przestrzeni ostatnich dwudziestu lat, dotyczący tak obecnych, jak przeszłych dziejów życia organicznego, dostarczył ogromu faktów, które powinny zapewnić wystarczającą podstawę dla sformułowania ogólnego prawa, które nie tylko obejmie i wyjaśni wszystkie te fakty, ale także nakreśli kierunek nowych badań. Idea takiego prawa pojawiła się w umyśle autora niniejszego artykułu jakieś dziesięć lat temu. * Od tego czasu wykorzystywał on każdą nadarzającą się okazję, aby przetestować je w odniesieniu do wszystkich nowo odkrytych faktów, o których się dowiedział, albo tych, które sam zaobserwował. Wszystko to przekonało go o słuszności jego hipotezy. Zagłębienie się w tę problematykę zajęłoby wiele miejsca i tylko ze względu na pewne ostatnie opinie, które wydały się autorowi błędne, zdecydował się on podjąć ryzyko i publicznie przedstawić swoje poglądy, posiłkując się jedynie takimi oczywistymi argumentami i przykładami, na jakie mógł sobie pozwolić w miejscu tak odległym od wszelkich publikacji przyrodniczych.

Poniższe twierdzenia z dziedzin geografii organizmów żywych i geologii przedstawiają najważniejsze fakty, które stanowią podstawę wyżej wspomnianej hipotezy.

\section{Geografia}

1. Duże grupy, takie jak gromady i rzędy, są na ogół rozproszone na całej Ziemi, podczas gdy występowanie tych mniejszych, jak rodzin i rodzajów, jest często zawężone do jednego regionu, nierzadko do bardzo niewielkiego obszaru.

2. Zakres występowania rodzajów w szeroko rozmieszczonych rodzinach jest często ograniczony, a wyraźnie wyodrębnione grupy gatunków w szeroko rozprzestrzenionych rodzajach są charakterystyczne dla każdego obszaru geograficznego.

\footnotetext{
* (Przyp. thum.) Wallace został ewolucjonistą po lekturze anonimowo opublikowanej książki Vestiges of the Natural History of Creation - jej autorem, jak się później okazało, był Robert Chambers (por. Alfred Russel Wallace, My Life: A Record of Events and Opinions, vol. I, Chapman \& Hall, London 1905, s. 254-255). Obszerne studium poglądów Chambersa przedstawił w setną rocznicę opublikowania O powstawaniu gatunków Milton Millhauser (por. Milton MiLLHAuser, Just Before Darwin: Robert Chambers and Vestiges, Wesleyan University Press, Middletown 1959).
} 
3. Kiedy dana grupa jest ograniczona do jednego obszaru i bogata w gatunki, to niemal zawsze najbliżej spokrewnione gatunki znajdowane są w tych samych lub okolicznych miejscach i dlatego naturalne następstwo gatunków pod względem pokrewieństwa ma także charakter geograficzny.

4. W krajach o podobnym klimacie, ale oddzielonych szerokim morzem lub wysokimi górami, rodzinom, rodzajom i gatunkom w jednym kraju odpowiadają blisko spokrewnione rodziny, rodzaje i gatunki w innym kraju.

\section{Geologia}

5. Rozmieszczenie świata organicznego w czasie jest bardzo podobne do jego obecnego rozmieszczenia w przestrzeni.

6. Większość dużych i kilka mniejszych grup organizmów rozciąga się na kilka okresów geologicznych.

7. W każdym okresie istnieją jednak charakterystyczne grupy organizmów, które nie występują nigdzie indziej i które rozciągają się na jedną lub kilka formacji geologicznych.

8. Gatunki jednego rodzaju lub rodzaje jednej rodziny występujące w tym samym czasie geologicznym są bliżej spokrewnione niż te pojawiające się w różnych epokach.

9. Na podstawie rozmieszczenia geograficznego widać, że żaden gatunek czy rodzaj nie występuje zazwyczaj w dwóch odległych miejscach, nie zajmując jednocześnie miejsc pośrednich, i podobnie w geologii istnienie gatunku czy rodzaju ma charakter ciągły. Innymi słowy, żadna grupa lub żaden gatunek nie powstał dwukrotnie.

10. Z powyższych faktów można wyprowadzić następujące prawo: Każdy gatunek pojawit się wspótzależnie w czasie i przestrzeni z wcześniej istniejacym i blisko spokrewnionym gatunkiem.

Prawo to stanowi wyjaśnienie i ilustrację dla wszystkich faktów mających związek z poniższymi zagadnieniami: 
1. System naturalnego pokrewieństwa.

2. Rozmieszczenie zwierząt i roślin w przestrzeni.

3. Rozmieszczenie zwierząt i roślin w czasie, włączając $w$ to wszystkie przejawy reprezentatywnych grup organizmów i tych, które, jak przypuszczał Profesor Forbes, ${ }^{*}$ wykazują biegunowość. ${ }^{* *}$

4. Występowanie narządów szczątkowych.

Spróbujemy krótko wykazać, jak wyżej nakreślone prawo stosuje się do przedstawionych zagadnien.

Jeżeli jest ono prawdziwe, to naturalne łańcuchy pokrewieństwa będą przedstawiały kolejność, w jakiej pojawiały się poszczególne gatunki, z których każdy wywodził się od blisko spokrewnionych gatunków obecnych w chwili ich pojawienia się. Z pewnością możliwe jest, że dwa czy trzy różne gatunki mogły mieć wspólnego przodka, a każdy z nich mógł dać początek innym blisko spokrewnionym gatunkom. Zatem tak długo, jak każdy gatunek będzie przodkiem tylko jednego zbliżonego sobie gatunku, to ciąg pokrewieństwa będzie prosty i może być przedstawiony przez umieszczenie poszczególnych gatunków w bezpośrednim następstwie $\mathrm{w}$ linii prostej. Jeżeli jednak co najmniej dwa gatunki pochodziłyby od różnych wspólnych przodków, wówczas łańcuch pokrewieństwa będzie złożony i może zostać przedstawiony jedynie za pomocą rozwidlonej lub rozgałęzionej linii. Wszystkie próby sporządzenia naturalnej klasyfikacji i uporządkowania organizmów żywych pokazują, że obydwa scenariusze zrealizowały się w stworzeniu. Łańcuchy pokrewieństw czasem może dobrze ilustrować bezpośrednie przejście od gatunku do gatunku albo od grupy do grupy, ale jest tak zazwyczaj tylko w ograniczonym zakresie. Nieustannie natrafiamy na co najmniej dwie modyfikacje jednego lub dwóch różnych narządów, co prowadzi

\footnotetext{
* (Przyp. thum.) Edward Forbes (1815-1854), brytyjski zoolog, geolog, paleontolog. Forbes interesował się także zagadnieniem biogeografii. Był on krytykiem poglądu o transmutacji gatunków, a pod koniec życia przedstawił hipotezę biegunowości, która wskazywała na nadnaturalne pochodzenie organizmów żywych.

** (Przyp. thum.) Edward Forbes, „On the Manifestation of Polarity in the Distribution of Organized Beings in Time", Proceedings of the Royal Institution of Great Britain 1854, vol. I, s. 428-433; Edward Forbes, „Anniversary Address of the President”, The Quarterly Journal of the Geological Society of London 1854, vol. 10, s. xxii-lxxxi.
} 
nas do wniosku o istnieniu dwóch odmiennych linii gatunków, które ostatecznie rozgałęziają się tak bardzo, że tworzą odrębne rodzaje czy rodziny. Według przyrodników są to paralelne lub reprezentatywne grupy, które często występują w różnych krajach lub są znajdowane w postaci skamieniałości w różnych formacjach geologicznych. Gdy są tak oddalone od wspólnego przodka, że różnią się w wielu istotnych cechach fizycznych, uznaje się je za analogiczne, choć nadal zachowują rodzinne podobieństwo. Widzimy więc, jak trudno jest rozstrzygnąć w każdym przypadku, czy dany związek jest analogią czy pokrewieństwem, ponieważ kiedy cofamy się wzdłuż linii paralelnej lub rozgałęzionej w kierunku wspólnego przodka, analogia pomiędzy dwiema grupami staje się pokrewieństwem. Jesteśmy także świadomi, że nawet w małej i bardzo dobrze ustalonej grupie istnieją trudności w sporządzeniu prawdziwej klasyfikacji w obecnym stanie natury jest to niemal niemożliwe. Tak liczne gatunki oraz tak różnorodne modyfikacje formy i struktury pochodzą prawdopodobnie od ogromnej liczby gatunków, które były przodkami obecnych gatunków, a w konsekwencji odpowiadają za skomplikowane rozgałęzienia linii pokrewieństwa, tak zawiłe, jak rozgałęzienia sękatego dębu lub układ krwionośny ludzkiego ciała. I jeżeli uwzględnimy to, że dysponujemy jedynie fragmentaryczną wiedzą o tym ogromnym systemie, w którym pień i główne gałęzie reprezentowane są przez nieznane nam wymarłe gatunki, a zbadać należy ogromną liczbę gałęzi, konarów, drobnych gałązek i rozrzuconych liści oraz właściwie ustalić ich pierwotne umiejscowienie w relacji do pozostałych elementów, wówczas cała trudność sporządzenia prawdziwego naturalnego systemu klasyfikacji stanie się dla nas wyraźna.

Powinniśmy zatem poczuć się w obowiązku do odrzucenia wszystkich systemów klasyfikacji, które albo umieszczają gatunki lub grupy w kołach, albo ustalają ściśle określoną liczbę dla podziałów każdej grupy. * Drugi z nich, po-

\footnotetext{
* (Przyp. tłum.) Wallace pisał o piątkowym (kołowym) systemie klasyfikacji organizmów żywych autorstwa Williama S. MacLeaya (por. William S. MAcLeaY, Horae entomologica: or, Essays on the Annulose Animals, S. Bagster, London 1819), który został rozpowszechniony przez Williama Swainsona (por. William SwaInson, A Treatise on the Geography and Classification of Animals, Longman, Rees, Orme, Brown, Greene and Longman, and John Taylor, London 1835; William SwaInson, On the Natural History and Classification of Birds, vol 1-2, Longman, Rees, Orme, Brown, Green, and Longman, London 1836). O dziewiętnastowiecznych systemach taksonomicznych pisał szerzej Peter J. Bowler (por. Peter J. Bowler, Historia nauk o środowisku,
} 
mimo zręczności jego zwolenników, został powszechnie odrzucony przez przyrodników jako niezgodny ze stanem przyrody. Lepiej ugruntowany kołowy system pokrewieństwa cieszył się większym zainteresowaniem i przez wielu wybitnych przyrodników został do pewnego stopnia przyjęty. Nigdy jednak nie byliśmy w stanie znaleźć przypadku, w którym koło byłoby domknięte przez bezpośrednie i bliskie pokrewieństwo. W wielu przypadkach oczywiste podobieństwo nie zostało rozpoznane, a pokrewieństwo było bardzo niewyraźne lub zupełnie wątpliwe. Koncepcja skomplikowanego rozgałęziania się linii pokrewieństwa w obszerne grupy umożliwia lepsze wykazanie słabości jakichkolwiek prób całkowicie sztucznego uporządkowania. Śmiertelny cios podobnym usiłowaniom zadał nieodżałowany pan Strickland ${ }^{*}$ w znakomitym artykule opublikowanym na łamach Annals of Natural History, w którym tak jasno przedstawił prawdziwie syntetyczną metodę odkrywania Systemu Naturalnego. ${ }^{* *}$

Jeżeli rozważymy rozmieszczenie geograficzne zwierząt i roślin na Ziemi, to okaże się, że wszystkie fakty są nadzwyczaj zgodne z przyjętą hipotezą i można je łatwo wyjaśnić w jej świetle. Specyficzne dla danego kraju gatunki, rodzaje i całe rodziny będą nieodzownym skutkiem długotrwałej izolacji, wystarczającej do powstania wielu pokoleń gatunków wywodzących się od wcześniej istniejących organizmów. I dlatego, że organizmy te wymarły, podobnie jak ich poprzednicy, pozostałe grupy jawić się będą jako odizolowane. Jeżeli jednak w jakimś przypadku wcześniejszy gatunek miał szeroki zakres występowania, to mógł on dać początek co najmniej dwóm różnym grupom gatunków, tworząc tym samym rozmaite reprezentatywne lub analogiczne grupy. Europej-

przeł. Joanna Popiołek, Wiesław Studencki, Wydawnictwa Uniwersytetu Warszawskiego, Warszawa 2007, s. 204-214). Por. też Robert J. O'HarA, „Diagrammatic Classifications of Birds, 18191901: Views of the Natural System in 19th-century British Ornithology”, w: Henri Ouellet (ed.), Acta XIX Congressus Internationalis Ornithologici, vol. II, University of Ottawa Press (National Museum of Natural Science), Ottawa 1988, s. 2746-2759.

* (Przyp. thum.) Hugh E. Strickland (1811-1853), angielski geolog i ornitolog, zainteresowany także zagadnieniem systematyki zwierząt. Jeden z założycieli Towarzystwa im. Johna Raya.

** (Przyp. thum.) Por. Hugh E. Strickland, „On the True Method of Discovering the Natural System in Zoology and Botany", Annals of Natural History; or, Magazine of Zoology, Botany, and Geology 1840, vol. VI, s. 184-194. 
skie Sylviadce, ${ }^{*}$ północno-amerykańskie Sylvicolidee, ${ }^{* *}$ południowo-amerykańskie Heliconidce ${ }^{* * *}$ i wschodnie Euploeas, ${ }^{* * * *}$ a także grupa Trogonów zamieszkujących Azję i Amerykę Południową to przykłady, które można wyjaśnić tym sposobem.

Takie przypadki, jakie zachodzą na wyspach Galapagos, na których występują niewielkie grupy specyficznych roślin i zwierząt najbliżej spokrewnione z tymi z Ameryki Południowej, nie doczekały się dotychczas żadnego, nawet hipotetycznego wyjaśnienia. W skład archipelagu Galapagos wchodzi grupa bardzo wiekowych wysp wulkanicznych i prawdopodobnie nigdy nie znajdowały się one bliżej kontynentu niż ma to miejsce obecnie. Ich początkowe zasiedlanie, podobnie jak innych nowo powstałych wysp, odbywało się z pewnością na skutek działania wiatrów czy prądów oceanicznych. Po okresie dostatecznie dużym, by wymarły gatunki pierwotne, zachowały się tylko te, które uległy przekształceniom. W ten sam sposób możemy wyjaśnić oddzielone wyspy zamieszkałe przez specyficzne gatunki, zakładając, że albo wszystkie wyspy zostały zajęte równocześnie przez te same gatunki, które dały początek różnym modyfikacjom, albo że wyspy były stopniowo zasiedlane jedna po drugiej, ale na każdej nowe gatunki powstały z wcześniej istniejących organizmów. Podobnym przykładem jest także bardzo stara Wyspa Świętej Heleny, na której występują szczególne, choć ograniczone ilościowo, gatunki roślin. Z drugiej strony geologia nie dostarcza informacji o żadnej nowo powstałej wyspie (na przykład w późnym Trzeciorzędzie), którą zamieszkiwałyby specyficzne dla niej rodzaje, rodziny albo chociaż liczne gatunki.

Gdy łańcuch górski ulegnie wysokiemu wypiętrzeniu i będzie trwał w tym stanie na przestrzeni długiej epoki geologicznej, to gatunki po obu stronach jego podnóża będą często bardzo różne. Pojawią się wówczas gatunki reprezentatywne dla niektórych rodzajów, a nawet całe rodzaje będące szczególne dla jednej ze stron, co jest zadziwiająco dobrze widoczne w wypadku Andów i Gór Skali-

\footnotetext{
* (Przyp. tłum.) Rodzina ptaków z rzędu wróblowych.

** (Przyp. tłum.) Rodzina owadów z rzędu muchówek.

*** (Przyp. thum.) Rodzina owadów z rzędu motyli.

**** (Przyp. tłum.) Rodzaj motyli z rodziny rusałkowatych.
} 
stych. Podobne zjawiska zachodzą, kiedy wyspa oddziela się od kontynentu w bardzo wczesnym okresie. Płytkie morze między Półwyspem Malajskim, Jawą, Sumatrą i Borneo było we wczesnej epoce prawdopodobnie kontynentem lub wielką wyspą, która mogła ulec zatopieniu, gdy wypiętrzały się wulkaniczne obszary Jawy i Sumatry. Skutkami tego organicznego procesu jest ogromna liczba gatunków zwierząt wspólnych dla niektórych lub wszystkich wyżej wymienionych azjatyckich wysp. Istnieje jednakże pokaźna liczba blisko spokrewnionych gatunków, szczególnych dla każdej z wysp, co wskazuje na ogromne odstępy czasu, które upłynęły od momentu ich rozłączenia. Gdyby zasady, za którymi opowiada się autor niniejszego artykułu, zostały dobrze opracowane, fakty dotyczące rozmieszczenia geograficznego i geologii mogłyby w wątpliwych wypadkach wzajemnie się wyjaśniać.

We wszystkich tych przypadkach, kiedy wyspa oddzieliła się od kontynentu lub wyłoniła z morza pod wpływem działania wulkanów lub koralowców albo gdy łańcuch górski uległ wypiętrzeniu w niedawnej epoce geologicznej, nigdy nie pojawily się przypadki szczególnych grup organizmów czy nawet pojedynczych gatunków reprezentatywnych. Nasza własna wyspa jest tego przykładem. $\mathrm{Z}$ punktu widzenia geologii jej odłączenie od kontynentu nastąpiło w niedalekiej przeszłości i dlatego występuje na niej niewielka liczba specyficznych gatunków. Podobnie rzecz wygląda w wypadku Alp, jednego z najmłodszych łańcuchów górskich. Alpy oddzielają faunę i florę, która nie różni się bardziej niż można by oczekiwać przy uwzględnieniu jedynie wpływu klimatu i szerokości geograficznej.

Najbardziej uderzające i ważne fakty wiążące się z twierdzeniem numer trzy ${ }^{*}$ dotyczą blisko spokrewnionych gatunków żyjących w licznych grupach, które sąsiadują ze sobą. Pan Lovell Reeve dobrze zobrazował to w użytecznej $\mathrm{i}$ interesującej pracy „On the Geographical Distribution of the Bulimi” [O rozmieszczeniu geograficznym Bulimi]. ${ }^{* *}$ Zależność ta, jak mieliśmy okazję zaob-

\footnotetext{
* (Przyp. thum.) „Kiedy dana grupa jest ograniczona do jednego obszaru i bogata w gatunki, to niemal zawsze najbliżej spokrewnione gatunki znajdowane są w tych samych lub okolicznych miejscach i dlatego naturalne następstwo gatunków pod względem pokrewieństwa ma także charakter geograficzny".

** (Przyp. thum.) Lovell A. Reeve, „On the Geographical Distribution of the Bulimi, a Genus of Terrestrial Mollusca, and On the Modification of Their Shell to the Local Physical Conditions
} 
serwować, widoczna jest także w wypadku kolibrów, tukanów czy też w niewielkich grupach dwóch lub trzech blisko spokrewnionych gatunków, które często znajduje się w tych samych lub sąsiednich regionach. Kolejnymi organizmami, których rozmieszczenie dostarcza podobnych dowodów na rzecz powyższego twierdzenia, są ryby. Każda większa rzeka posiada specyficzne dla siebie rodzaje ryb, a w bogatszych rodzajach grupy blisko spokrewnionych gatunków. Ale tak samo rzecz wygląda w całej przyrodzie — każda gromada i rząd organizmów żywych dostarczy podobnych faktów. Dotychczas nie podejmowano żadnych prób wyjaśnienia tych niezwykłych zjawisk albo pokazania ich źródeł. Dlaczego rodzaje drzew palmowych i orchidei niemalże w każdym przypadku występują na jednej półkuli? Dlaczego blisko spokrewnione gatunki trogona $\mathrm{z}$ brązowo upierzonym grzbietem znajdowane są jedynie na wschodzie, a te $\mathrm{z}$ zielonym grzbietem na zachodzie? Dlaczego podobne ograniczenia geograficzne występują w wypadku ar i kakadu? Owady dostarczają niezliczoną liczbę podobnych przykładów: afrykańskie Goliathi, ${ }^{*}$ zamieszkujące wyspy oceanu indyjskiego Ornithopterce, ${ }^{* *}$ południowo-amerykańskie Heliconidee, ${ }^{* * *}$ wschodnie Danaid $c{ }^{* * * *}$ oraz wszystkie najbliżej spokrewnione gatunki, które występują na tych samych obszarach geograficznych. Dlaczego tak jest? Pytanie to nasuwa się każdemu, kto się nad tym problemem zastanawiał. Nie obserwowalibyśmy tych faktów, gdyby nie istniało prawo, które kierowało pojawianiem się i rozmieszczeniem poszczególnych gatunków. Prawo tutaj wyrażone nie tylko wyjaśnia obserwowane fakty, ale także sprawia, że jawią się one jako konieczne, a ogromne i długotrwałe zmiany geologiczne zachodzące na Ziemi z łatwością uzasadniają występujące niekiedy wyjątki i duże rozbieżności. Autor przedstawił swoje niedostatecznie jeszcze wypracowane poglądy z nadzieją, że zostaną one sprawdzone przez innych przyrodników, a w wypadku opinii krytycznych pozna on wszystkie potencjalnie niezgodne z nimi fakty. Jako że jego hipoteza

in which the Species Occur", The Annals and Magazine of Natural History, Including Zoology, Botany, and Geology 1851, vol. VII (Second Series), s. 241-255.

* (Przyp. tłum.) Rodzaj chrząszcza z rodziny poświętnikowatych.

** (Przyp. tłum.) Gatunek motyla z rodzaju Ornithoptera.

*** (Przyp. thum.) Rodzina owadów z rzędu motyli.

**** (Przyp. tłum.) Podrodzina owadów z rzędu motyli. 
łączy i wyjaśnia fakty występujące w przyrodzie, oczekuje on, że ewentualne próby jej obalenia polegać będą właśnie na przytaczaniu odpowiednich faktów, nie zaś na formułowaniu apriorycznych argumentów podważających jej prawdopodobieństwo.

Rozmieszczenie geologiczne organizmów żywych jest dokładnie analogiczne do geograficznego. Blisko spokrewnione gatunki zajmują te same terytoria, a zmiany od gatunku do gatunku wydają się zachodzić stopniowo tak w czasie, jak i w przestrzeni. Chociaż geologia dostarcza nam wystarczających świadectw wymierania i pojawiania się gatunków, to jednak nie wyjaśnia, w jaki sposób każdy z tych procesów zachodzi. Proces wymierania gatunków nie nastręcza większych trudności, a modus operandi został dobrze przedstawiony przez Sir Charlesa Lyella ${ }^{*}$ w zachwycających Principles of Geology [Zasadach geologii]. ${ }^{* *}$ Zmiany geologiczne, pomimo że zachodzą stopniowo, muszą w konsekwencji wpływać na zmianę warunków środowiskowych do tego stopnia, że istnienie niektórych gatunków staje się niemożliwe. Wygaśnięcie poszczególnych gatunków w większości wypadków mogło być spowodowane przez ich stopniowe wymieranie, ale w niektórych sytuacjach mogło dojść też do nagłej eliminacji gatunków zajmujących niewielkie obszary. Odkrycie, w jaki sposób w obecnym okresie geologicznym wypełniane są luki po wygasłych gatunkach, przysparza wielu trudności, ale zarazem jest to najbardziej interesujące zagadnienie w historii naturalnej Ziemi. ${ }^{* * *}$ Dociekania współczesnych przyrodników, którzy ze znanych faktów usiłują wyprowadzić prawo określające, jakie gatunki mogły i jakie pojawiły się w danej epoce, mogą, miejmy nadzieję, być uważane za krok we właściwym kierunku do pełnego wyjaśnienia.

* (Przyp. tłum.) Charles Lyell (1797-1875), wybitny angielski geolog i autor trzytomowego dzieła Principles of Geology, na stronach którego opowiedział się za uniformitaryzmem. Twierdził, że współczesna powierzchnia Ziemi jest wynikiem oddziaływania długotrwałych, naturalnych procesów przyrodniczych, a nie globalnych katastrof. Lyell był wieloletnim przyjacielem Karola Darwina, jednak nigdy nie zaakceptował w pełni teorii ewolucji drogą doboru naturalnego.

** (Przyp. thum.) Charles Lyell, Principles of Geology, vol. 1, John Murray, London 1830; vol. 2, John Murray, London 1832; vol. 3, John Murray, London 1833.

*** (Przyp. thum.) Zagadnienie powstawania nowych gatunków zostało określone przez Darwina mianem „tajemnicy tajemnic” (por. Marc EReshefsky, „Mystery of Mysteries: Darwin and the Species Problem", Cladistics 2011, vol. 27, s. 67-79). 
W ostatnich latach wiele dyskusji poświęcono pytaniu czy następstwo pojawiania się form żywych na Ziemi urzeczywistniało się od niższych do wyższych stopni organizacji. Poznane fakty skłaniają do wniosku, że pogląd o postępującej złożoności organizmów nie zawsze się potwierdza. Mięczaki i promieniste istniały przed kręgowcami, a wzrost stopnia organizacji od ryb do gadów i ssaków, a także od ssaków niższych do wyższych, jest bezdyskusyjny. Z drugiej strony twierdzi się, że mięczaki i promieniste $\mathrm{z}$ bardzo wczesnych epok znajdowały się na wyższym poziomie organizacji niż ogromna liczba obecnie istniejących i że pierwsze odkryte ryby nie znajdują się z pewnością na najniższym stopniu organizacji w tej gromadzie. Wydaje się, że przedstawiona hipoteza uzgodni ze sobą wszystkie te fakty i w ogromnej większości przypadków je wyjaśni. I chociaż niektórym czytelnikom może wydawać się czystą teorią postępu, to w rzeczywistości mówi ona jedynie o stopniowych zmianach. Bez wątpienia nietrudno jednak pokazać, że rzeczywista progresja w stopniu organizacji jest zupełnie zgodna nie tylko z wszystkimi zjawiskami w świecie organicznym, ale także z wyraźną retrogresją, jeśli miałaby ona miejsce.

Wracając do analogii rozgałęzionego drzewa jako do najlepszego sposobu przedstawienia naturalnego rozmieszczenia gatunków i ich kolejnego pojawiania się, przypuśćmy, że jakaś grupa (powiedzmy z gromady mięczaków) we wczesnej epoce geologicznej osiągnęła ogromne bogactwo gatunków i wysoki stopień organizacji. Przypuśćmy teraz, że ta ogromna gałąź spokrewnionych gatunków uległa całkowitemu lub częściowemu wymarciu na skutek zmian geologicznych. W tej sytuacji ze starego pnia wyrośnie nowa gałąź, innymi słowy: pojawią się nowe gatunki, których przodkami będą te same, znajdujące się na niższym poziomie organizacji gatunki, będące zarazem przodkami wcześniejszej grupy, która w odróżnieniu od tej nowej nie przetrwała próby zmieniających się warunków środowiskowych. Budowa i organizacja nowo powstałej grupy gatunków będzie posiadała stosowne dla nowych warunków zewnętrznych modyfikacje i stanie się grupą reprezentatywną dla organizmów w kolejnej formacji geologicznej. Może się jednak zdarzyć, że nowe gatunki nigdy nie osiągną tak wysokiego stopnia organizacji jak gatunki je poprzedzające, których wymarcie zwolniło miejsce innym zmodyfikowanym organizmom pochodzącym od tej samej grupy, które z kolei mogłyby różnić się od swoich poprzedników ze względu na stopień organizacji, liczebność gatunków czy różnorodność 
form i struktur. Należy podkreślić, że żadna z tych grup nie musiała całkowicie wygasnąć. Mogło zachować się kilka gatunków, których przekształceni potomkowie istnieliby w każdym następnym okresie jako wyblakła pamiątka ich minionego blasku i obfitości. Dlatego każdy przypadek tego, co wygląda na retrogresję, może w rzeczywistości oznaczać progresję, chociaż przerywaną — kiedy jakiś dominujący gatunek wymrze, może on zostać zastąpiony przez słaby i ułomny zamiennik. Powyższe uwagi wydają się stosować do mięczaków, które we wczesnym okresie osiągnęly wysoki stopień organizacji i ogromną różnorodność form oraz gatunków oskorupionych głowonogów. W każdej kolejnej epoce zmodyfikowane gatunki i rodzaje zajmowały miejsce organizmów wymarłych, z których we współczesnej erze zachowało się jedynie kilku niewielkich przedstawicieli wcześniejszych mięczaków, podczas gdy brzuchonogi i skorupiaki uzyskały ogromną przewagę. W okresie długotrwałych zmian zachodzących na Ziemi proces jej zasiedlania przez organizmy żywe trwał nieustannie i kiedy tylko któraś z wyżej zorganizowanych grup była bliska wymarciu lub zupełnie wymarła, niższe formy, które przetrwały zmieniające się warunki środowiskowe, stawały się prekursorami nowych ras. Wydaje się, że jedynie w ten sposób można wyjaśnić wszystkie przypadki występowania reprezentatywnych grup w kolejnych okresach, jak również wzrosty i spadki poziomu organizacji.

Hipoteza biegunowości została wyłożona niedawno przez profesora Edwarda Forbesa ${ }^{1} \mathrm{w}$ celu wyjaśnienia obfitości form rodzajowych we wczesnych okresach i współcześnie, jak również ich stopniowego ubożenia w epokach przejściowych aż do osiągnięcia minimalnej ich ilości w paleozoiku i drugorzędzie. Hipoteza ta wydaje się zupełnie zbędna, jako że fakty przyrodnicze można łatwo wytłumaczyć na gruncie przyjętych tu zasad. Zgodnie z poglądem profesora Forbesa rzadko zdarza się, aby między okresami paleozoiku i neozoiku występował jakiś wspólny gatunek, ale też większość rodzajów i rodzin zniknęła i została zastąpiona nowymi. Zasadniczo przyjmuje się, że taka zmiana w świecie organicznym musi zachodzić przez ogromne okresy czasu. Nie dysponujemy jednak zapisem kopalnym z tego okresu. Jest tak prawdopodobnie dlatego, że

\footnotetext{
${ }^{1}$ Skoro o tym mowa, autor niniejszego artykułu z wielkim ubolewaniem usłyszał o śmierci tego wybitnego przyrodnika, po którym tak wiele się spodziewano. Jego uwag na temat niniejszego artykułu - poruszającego tematykę, w której był on bez wątpienia osobą o wiele bardziej kompetentną - oczekiwał on z największym zainteresowaniem. Któż mógłby teraz go zastąpić?
} 
wszystkie wczesne formacje dostępne współczesnym przyrodnikom zostały wyniesione pod koniec paleozoiku na czas umożliwiający zmiany organiczne, które doprowadziły do powstania fauny i flory drugorzędu. Zapis tego okresu przejściowego został pogrzebany pod dnem oceanu, który pokrywa 3/4 powierzchni globu. Wydaje się wysoce prawdopodobne, że długi okres stabilności warunków fizycznych danego obszaru będzie najbardziej sprzyjał istnieniu życia organicznego w największej obfitości - dotyczy to zarówno osobników, odmian gatunków czy grup rodzajowych. Obecnie dochodzimy do wniosku, że miejsca najlepiej przystosowane do nagłego zwiększenia liczebności i rozwoju osobników są najbogatsze w gatunki i we wspaniałe odmiany — porównajmy na przykład regiony tropikalne $\mathrm{z}$ regionami umiarkowanymi czy arktycznymi. $\mathrm{Z}$ drugiej strony wydaje się nie mniej prawdopodobne, że zmiana warunków środowiskowych danego obszaru - nawet nieznaczna, ale gwałtowna, albo stopniowa, lecz znaczna - okaże się wysoce niekorzystna dla przetrwania osobników, co może skutkować nie tylko wymarciem wielu gatunków, ale także być wysoce niekorzystne dla pojawienia się nowych. W tym przypadku również możemy dostrzec pewną analogię do obecnego stanu Ziemi, gdyż ogromne i gwałtowne zmiany warunków środowiskowych, a nie ich stabilność w strefach umiarkowanych i podbiegunowych, sprawia, że w odróżnieniu od regionów tropikalnych nie sprzyjają one zwiększeniu liczebności gatunków. Dobrą tego ilustracją jest wielka przestrzeń blisko regionów tropikalnych, do której, o ile klimat jest zbliżony, napływają organizmy tropikalne, a także bogactwo gatunków górzystych regionów tropikalnych, które swoim jednostajnym klimatem różnią się zasadniczo od strefy umiarkowanej. W każdym razie słuszne wydaje się przypuszczenie, że nowe, znane nam gatunki pojawiły się w czasie niewielkich zmian geologicznych i że więcej gatunków powstawało niż wymierało, prowadząc do wzrostu ich liczebności. $Z$ drugiej strony wydaje się, że w okresie zwiększonej aktywności geologicznej przyrost naturalny może być ujemny i wskutek tego liczba gatunków będzie malała. Na rzecz tezy, że czynnikiem decydującym w procesie powstawania i wymierania gatunków są warunki środowiskowe, przemawiają świadectwa uzyskane z formacji węgla, gdzie uskoki i zakrzywienia obrazują okres wzmożonej aktywności geologicznej i nagłych wstrząsów, wskutek czego kolejna formacja charakteryzuje się wyraźnym ubóstwem organizmów żywych. Dlatego możemy jedynie zakładać istnienie długiego, ale nieznanego okresu pod koniec paleozoiku, który charakteryzował się wzmożoną aktywnością geo- 
logiczną, a następnie etapu stabilizacji w okresie drugorzędu pozwalającego na ponowne, stopniowe zasiedlanie Ziemi różnorodnymi formami organicznymi. W ten sposób można wyjaśnić wszystkie fakty. Uzyskaliśmy zatem, odwołując się wyłącznie do znanych nam przyczyn i wyprowadzanych z nich skutków, wskazówkę dotyczącą wzrostu liczebności form życia podczas jednych okresów geologicznych i ich zmniejszenia się w czasie innych. Skutki zmian geologicznych wczesnych formacji na organizmy żywe są tak niesłychanie trudne do ustalenia, że kiedy możemy wyjaśnić istotne fakty tymczasowym spowalnianiem i przyśpieszaniem procesu fizycznego, który — co wiemy ze znajomości jego natury i z obserwacji - jest niejednostajny, to tak proste uzasadnienie może być z pewnością bardziej użyteczne niż problematyczna hipoteza biegunowości.

Podejmę także próbę przedstawienia pewnych argumentów podważających słuszność teorii profesora Forbesa. Nasza wiedza dotycząca świata organicznego jakiejkolwiek epoki geologicznej jest z konieczności bardzo niedoskonała. $\mathrm{Z}$ drugiej strony, patrząc na ogromną liczbę gatunków odkrytych przez geologów, wydaje się to wątpliwe. Jeżeli jednak porównamy ją nie tylko z liczbą gatunków żyjących obecnie, lecz również z organizmami wymarłymi, to okaże się ona mocno zaniżona. ${ }^{2}$ Nie mamy żadnych powodów sądzić, że liczba gatunków lądowych jakiejkolwiek minionej epoki była dużo mniejsza niż obecnie. W każdym razie liczba gatunków wodnych, najlepiej poznanych przez geologów, była prawdopodobnie często równie wielka lub większa. Obecnie wiemy, że zaszło wiele przypadków, w których jedna grupa gatunków została zastąpiona przez drugą. Nowe grupy organizmów wielokrotnie zajmowały miejsce wcześniej wymarłych i dlatego całkowita liczba gatunków, które zamieszkiwały Ziemię od najwcześniejszych okresów geologicznych, musiała utrzymywać się w równowadze aż do czasów obecnych. W podobnej równowadze utrzymała się cała rasa

\footnotetext{
${ }^{2}$ Por. artykuł Profesora Agassiza opublikowany na łamach Annals z listopada 1851 (przyp. red.).

(Przyp. thum.) Louis Agassiz, „The Primitive Diversity and Number of Animals in Geological Times", Annals and Magazine of Natural History 1854, vol. XIV (Second Series), s. 350-366. Artykuł pierwotnie ukazał się w tomie American Journal of Science and Arts w maju 1854 roku (Second Series, vol. XVII, s. 309-324). Teskt został przedrukowany w tym samym roku także w: The Edinburgh New Philosophical Journal (vol. LVII, April-October, s. 271-292).
} 
ludzka. Zatem powierzchnia Ziemi w każdej epoce była bez wątpienia teatrem życia, podobnym do tego, który istnieje obecnie. Kiedy wymierały kolejne pokolenia każdego gatunku, to ich wylinka i części ciała mogące ulec zachowaniu pozostawiały ślad w każdej części istniejących wówczas mórz i oceanów, które — jak mamy powody sądzić - miały większy zasięg niż obecne. Aby zwiększyć zakres naszej wiedzy o wczesnym świecie i jego mieszkańcach, nie możemy badać jedynie powierzchni Ziemi, ale każdą formację geologiczną należy przeanalizować osobno i porównać ją z pozostałymi. Na przykład podczas syluru cała Ziemia była sylurska, a zwierzęta żyły i ginęły, pozostawiając ślady swojej obecności w większym lub mniejszym stopniu na całej powierzchni globu, i prawdopodobnie były (przynajmniej gatunki) niemal tak rozmaite na różnych szerokościach i długościach geograficznych jak ma to miejsce obecnie. Jaka część obszarów sylurskich zachowała się na całej powierzchni globu (większość rozległych obszarów syluryjskich znajduje się prawdopodobnie pod dnem oceanu) i jaka ich część została faktycznie zbadana pod kątem występowania skamieniałości? Czy pokłady skał znajdujące się w zasięgu naszych badań stanowią tysięczną czy dziesięciotysięczną część powierzchni Ziemi? Zadajmy te same pytania w odniesieniu do oolitu czy kredy lub chociażby do poszczególnych ich warstw, które różnią się ze względu na występujące w nich skamieniałości, a będziemy mieli wyobrażenie tego, jak niewielka cząstka całości jest nam znana.

O wiele ważniejsze jest jednak prawdopodobieństwo, a może nieomal pewność, że całe formacje zawierające zapis ogromnych okresów geologicznych są całkowicie pogrzebane pod dnem oceanu i na zawsze pozostaną poza zasięgiem naszych badań. Większość luk w zapisie kopalnym może jednak zostać wypełniona, a ogromna liczba pogrzebanych tam skamieniałości nieznanych i niewyobrażalnych zwierząt może pozostać dla nas tajemnicą jedynie do czasu, kiedy przyszłe procesy geologiczne sprawią, że staną się one dla nas dostępne. Wówczas skutecznie będzie można wyjaśnić pokrewieństwo licznych i odizolowanych grup będących nieustanną zagadką dla zoologów. Rozważania te muszą prowadzić do wniosku, że nasza wiedza na temat wielu wcześniejszych stworzeń żyjących na Ziemi jest z konieczności dalece niedoskonała i fragmentaryczna. Podobny byłby stopień naszej wiedzy o współczesnym świecie organizmów żywych, gdybyśmy byli zmuszeni do gromadzenia zbiorów i dokonywania obserwacji tylko w miejscach równie ograniczonych przestrzennie i ilościo- 
wo, jak te, które dają nam obecnie dostęp do skamieniałości. Hipoteza profesora Forbesa przyjmuje w gruncie rzeczy kompletność naszej wiedzy dotyczącej wszystkich organizmów żywych, jakie istniały na Ziemi. Niezależnie od pozostałych uwag, wydaje się, że na tej podstawie można sformułować najpoważniejszy zarzut przeciwko niej. Można bowiem powiedzieć, że podobne obiekcje pojawiają się względem każdej teorii dotyczącej zapisu kopalnego, ale nie jest to nieuchronne. Hipoteza przedłożona w niniejszym artykule w żadnym stopniu nie zależy od pełni naszej wiedzy o stanie minionego świata organicznego. Opiera się ona jedynie na posiadanych faktach będących fragmentami ogromnej całości, na podstawie których wyprowadzamy cząstkową wiedzę o naturze i zależnościach elementów tej całości, której szczegółów nigdy nie poznamy. Hipoteza ta oparta jest zatem na odizolowanych zbiorach faktów o świecie przyrody, dostrzega ich izolację i próbuje wyprowadzić z nich wiedzę o charakterze pozostałych części przyrody.

Narządy szczątkowe należą do kolejnej grupy istotnych faktów, które nie tylko są całkowicie zgodne z prawem wyłożonym na stronach niniejszego artykułu, ale także z konieczności z niego wynikają. W większości wypadków nie spełniają one ważnej roli w ekonomii zwierząt. Niemniej występowanie narządów szczątkowych zostało przyjęte już przez pierwszorzędnych specjalistów w zakresie anatomii porównawczej. ${ }^{*}$ Niewielkie kończyny ukryte pod skórą w wypadku wielu jaszczurek wężowatych, analne ostrogi u boa dusiciela, połączone kości palców w płetwie manata i wieloryba - to tylko niektóre szeroko znane przykłady. Podobne fakty występują także w botanice. Prątniczki, które nie wytwarzają pyłku kwiatowego, szczątkowe pąki kwiatowe i niewykształcone słupki kwiatów, należą do najczęstszych przypadków. Każdemu dociekliwemu przyrodnikowi musi nasuwać się pytanie: na czym polega funkcja organów szczątkowych? Jaki miały one związek z wielkimi prawami stworzenia? Czy nie uczą nas one czegoś o systemie przyrody? Jeżeli każdy gatunek został stworzony niezależnie i bez żadnego koniecznego związku z wcześniej istniejącymi gatunkami, to co oznacza obecność jawnie niedoskonałych organów szczątkowych? Ich istnienie musi mieć swoją przyczynę, muszą być one koniecznym re-

\footnotetext{
* (Przyp. thum.) Występowanie organów szczątkowych uznawali przed opublikowaniem dzieła O powstawaniu gatunków m.in.: Étienne Geoffroy Saint-Hilaire (1772-1844), Georges Cuvier (1769-1832), Richard Owen (1804-1892) czy Louis Agassiz (1807-1873).
} 
zultatem pewnego wielkiego prawa przyrody. Jeżeli, jak już starano się wykazać, istnieje wielkie prawo, które kieruje pojawianiem się nowych gatunków zwierząt i roślin, przy czym każda zmiana powinna zachodzić stopniowo i nie powinna pojawić się żadna istota, która swoim wyglądem będzie się znacząco różnić od wcześniej istniejących organizmów, to i w tym przypadku, jak zresztą wszędzie w przyrodzie, powinna istnieć ciągłość i harmonia, a występowanie organów szczątkowych należy uznać za konieczne i stanowiące zasadniczą część systemu przyrody. Przykładowo, ukształtowanie wyższych kręgowców wymagało wielu kroków, na tej drodze wiele organów musiało przejść modyfikacje od swojego pierwotnego stanu. W łuskowatej płetwie pingwina dostrzegamy nietypowy zarys skrzydła przystosowanego do latania, zaś jego kończyny, które na początku były ukryte pod skórą, a później zaczęły się spod niej nieco wysuwać, stanowiły konieczny stopień pośredni, zanim w pełni mogły wykształcić się te, które są w pełni przystosowane do lokomocji. Gdybyśmy odkryli wszystkie wymarłe gatunki, widzielibyśmy znacznie więcej takich modyfikacji, a także kompletniejszy zapis ich stopniowego rozwoju. Ogromne luki, które istnieją między rybami, gadami, ptakami i ssakami, zostałyby wówczas niewątpliwie zmniejszone przez formy pośrednie i cały świat organiczny byłby postrzegany jako system ciągły i harmonijny.

Powyżej przedstawiono, choć skrótowo i niedoskonale, jak prawo, zgodnie z którym „Każdy gatunek pojawił się współzależnie w czasie i przestrzeni z wcześniej istniejącym i blisko spokrewnionym gatunkiem", łączy ze sobą i tłumaczy ogromną liczbę niezależnych i dotychczas niewyjaśnionych faktów. Naturalny system uporządkowania istot żywych, ich geograficzny rozkład i następstwo w warstwach geologicznych, zjawiska reprezentatywności i wymienności grup we wszystkich ich modyfikacjach, a także najbardziej niezwykłe cechy szczególne budowy anatomicznej zostały przez powyższe prawo wyjaśnione i zilustrowane. Prawo to, jak się wydaje, nie tylko nie stoi w sprzeczności z żadnym $\mathrm{z}$ wielu współcześnie znanych faktów, ale jest z nimi całkowicie zgodne. Wykazuje ono także wyższość względem wcześniejszych hipotez, ponieważ nie tylko wyjaśnia istnienie czegoś, ale także tłumaczy, dlaczego to istnieć musi. W myśl tego prawa wiele najważniejszych zjawisk przyrodniczych musiało 
zajść, wynikają one z niego niemal z taką koniecznością jak eliptyczne orbity planet z prawa grawitacji.

Sarawak, Borneo, luty 1855.

Alfred Russel Wallace

\section{On the Law Which Has Regulated the Introduction of New Species}

\section{Summary}

The theme of present paper is the law that „Every species has come into existence coincident both in time and space with a pre-existing closely allied species". This law connects together and renders intelligible a vast number of independent and hitherto unexplained facts. The natural system of arrangement of organic beings, their geographical distribution, their geological sequence, the phenomena of representative and substituted groups in all their modifications, and the most singular peculiarities of anatomical structure, are all explained by it, in perfect accordance with the vast mass of facts which the researches of modern naturalists have brought together, and, it is believed, not materially opposed to any of them. It also claims a superiority over previous hypotheses, on the ground that it not merely explains, but necessitates what exists. Granted the law, and many of the most important facts in Nature could not have been otherwise, but are almost as necessary deductions from it, as are the elliptic orbits of the planets from the law of gravitation.

Keywords: geographical distribution, theory of polarity, Edward Forbes, rudimentary organs, system of natural affinities.

Slowa kluczowe: rozmieszczenie geograficzne, teoria biegunowości, Edward Forbes, organy szczątkowe, system naturalnego pokrewieństwa. 